\title{
Breaking Bad News: Doctors' Feelings and Behaviors
}

\author{
Fernanda Saviani-Zeoti and Eucia Beatriz Lopes Petean \\ Universidade de São Paulo, Brazil
}

\begin{abstract}
The announcement about the handicap of a child is communicated to parents by gynecologists or ultrasonographists, in the prenatal period. Often, these professionals are not prepared to communicate this news to the parents, and they have some limitations that lead them to act inappropriately. Therefore, the aims of this research were to identify and to describe the feelings of professionals facing this situation, and to examine their behaviors when they have to inform a couple about the child's anomaly. Ten gynecologists and ultrasonographists were interviewed: five were consultants in Public Health Services and five were private clinicians. Interviews were carried out with a semi-structured script. The results showed that, according to the participants, there is no specific moment, nor a standard behavior, that is most appropriate for making such an announcement. Yet the data show that all the participants feel hurt or frustrated when they must announce this phenomenon, becoming involved with the case. In conclusion, no graduate course has prepared them to deal with this deficiency. Suggestions are made concerning the graduate curriculum in order to improve the preparation of future doctors. A mental health professional is even necessary among the multidisciplinary team formed to deal with the pain produced in the moment of the announcement.

Keywords: medical formation, family and handicap, handicap, feelings
\end{abstract}

\begin{abstract}
Los ginecólogos o los ultrasonógrafos son los profesionales que deben comunicar a los padres la noticia de la discapacidad de su hijo, en el período prenatal. A menudo, estos profesionales no están preparados para comunicar este suceso a los padres y tienen algunas limitaciones que les llevan a actuar de forma inapropiada. Por ello, los objetivos de esta investigación eran identificar y describir las emociones de los profesionales que afrontan esta situación y conocer sus comportamientos cuando tienen que informar a una pareja de la anomalía de su hijo. Se entrevistaron a 10 ginecólogos y 10 ultrasonógrafos: 5 trabajaban en los Servicios de la Salud Pública y 5 eran clínicos privados. Las entrevistas eran semi-estructuradas. Los resultados muestran que, según los participantes, no hay un momento específico, ni un comportamiento estándar que sea el más apropiado para semejante situación. Sin embargo, los datos muestran que todos los participantes se sintieron dolidos o frustrados cuando tuvieron que informar de este fenómeno, y se involucraron en el caso. Concluyendo, no ha hay ningún curso de la licenciatura que los haya preparado para afrontar esta deficiencia. Se hacen algunas sugerencias acerca del currículo de licenciatura para mejorar la preparación de los futuros médicos. Incluso se necesita un procesional de la salud mental en los equipos multidisciplinarios que se forman para afrontar el dolor que se produce en el momento de semejante noticia.

Palabras clave: formación médica, familia y discapacidad, discapacidad, emociones
\end{abstract}

Correspondence concerning this article should be addressed to Fernanda Saviani Zeoti, Rua Professor Hoehne, 41. Sumarezinho CEP: 14055-27. Phone: (55) (16) 3630-9232. E-mail: saviani@ convex.com.br; or to Eucia Beatriz Lopes Petean, Av. Bandeirantes, 3900. Monte Alegre - Dept $^{\circ}$ de Psicologia e Educação/FFCLRP-USP- CEP: 14040-901. Phone: (55) (16) 3602-3767.E-mail: ebpetean@ @ffclrp.usp.br 
When a child is born with a handicap, it is not what the parents expected or hoped for. Every couple dreams of a perfect child, and when they learn that their dream-child has not been born, or will not be born, they feel a natural rejection for the actual child. The birth of a child involves a broad range of feelings. The birth of a handicapped child brings a feeling of inevitable rejection. It is not necessarily a rejection of the child, but of the problem that hindered the child from being the perfect and exemplary child of the couple's dreams (Assumpção Jr., 1991).

The parents experience a very emotionally turbulent period until they reorient themselves. Many studies point out one of the most delicate moments in this period: the time of notification. One of the most questioned issues is that of the how the abnormality becomes known, how the disclosure is made to the parents (Ramos, Hoffmann, \& Regen, 1985; Regen, Ardore, \& Hoffmann, 1993; Taanila, Jarvelin, \& Kokkonen, 1998; Vaidya, Greenberg, Patel, Strauss, \& Pollack, 1999).

The way that such a situation is communicated is extremely important, because the initial impact of telling the parents about an abnormality is almost always more disturbing than the actual physical presence of the abnormal child, with or without apparent impairment (Noronha \& Montgomery, 1993).

With the appearance of pre-natal diagnostics, this announcement has come to be made even earlier, and the task of communicating with the parents, which until now had been the responsibility of the pediatricians, now falls to the gynecologist or the obstetrician, as more and more pregnancies are being monitored with ultra-sound. Nowadays, the fetus, the embryo, the conception, and, even before this, the two reproductive cells that bring it to life can be directly observed, whether through ultra-sound, intrauterine photography, or even filming within the interior of the body. As a result of this monitoring, these days the ultrasonographist has also become a very important person at this time, frequently being the professional responsible for the notification (Wilheim, 1997; Quayle, 1997).

Most authors suggest that this disclosure be made to the couple in the clearest and most complete manner possible (without omissions), in accessible language, without the use of technical terminology (Regen et al., 1993; Taanila et al., 1998).

The study carried out by Taanila et al. (1998) indicated that younger parents of handicapped children feel more prepared to care for their children, as well as to deal with the handicap, than do older parents. This is because the younger parents were better informed regarding the handicap and received better practical counseling, which resulted in the parents' greater security and confidence in the team.

The importance of the doctor-patient relationship that fosters confidence in the parents is evident. Interpersonal communication skills associated with technical knowledge are essential to physicians, thus facilitating the relationship with the family and the information process. To be capable of providing a precise diagnosis is a matter of medical confidence, to be able to give the patients all the information they need reveals the medical art, but the wrong words can produce feelings of desperation and fragility and decrease the efficacy of the entire treatment (Hania, 2003).

The need for good communication has gradually come to be acknowledged in the literature (Buckman, 2002; Gauderer, 1981; Hania, 2003; Mast, Kindlimann, \& Langewitz, 2005; Redinbaugh et al., 2003), as well as in training to develop this type of skill in future doctors, and in those already in the field (Amiel et al., 2006; Buckman, 1992; Han, Keranen, Lescisin, \& Arnold, 2005; Hulsman, Mollema, Oort, Hoos, \& de Haes, 2006; Ptacek, Ptaceck, \& Ellison, 2001; Ungar, Alperin, Amiel, Beharier, \& Reis, 2002). This is because, among the doctors themselves, there is considerable consensus about the importance of learning communication skills at various stages of the medical education, and that there is a great deficiency in learning how to give bad news in the educational modules (Ungar et al.).

However, a good doctor should possess effective communication skills. Everyone expects this of their physician, but the truth is that good communication is generally very difficult, and training in this area is still developing. A technically well-prepared and emotionally balanced professional with a humanistic attitude about the handicap is very important in encouraging the mother-child bond, which is essential for the development of the child (Buckman, 2002; Buscaglia, 1993).

With the confirmation of an anomaly in the fetus, there is a tendency on the part of physicians to remain distant, which places doubt on their own competence, so that a feeling of anger rises about that child who has often not yet been born. A professional's unconscious feelings of guilt upon making a serious or fatal diagnosis is a little explored issue and may account for the doctor's difficulty to inform the patient of the diagnosis, thus creating tension in the doctor-patient relationship (Gauderer, 1981).

Thus, it is a fact that professionals working in the health area, especially doctors, must be prepared to communicate these events. However, it is worth noting that one can never guarantee appropriate behavior, as emotional and social factors are involved. Doctors may mix their own emotions in the interaction: feelings of sympathy, transference, their own frustration, anxiety, and so on. In any case, doctors cannot be expected to be the masters of absolute truth regarding everything in medicine, as they too have feelings and limitations that make them act in certain ways when confronted with the most diverse situations (Buckman, 2002; Vicente, 1994).

There are very few studies that examine this problem from the perspective of the physicians involved in the process, and, consequently, the feelings encountered by these professionals when faced with such a situation. There is much literature 
on medical communication but communication of bad news has received less attention. Little is known about doctors' behavior while giving bad news or how their delivery of such news is perceived. Most of such studies stress the need for new studies that focus on doctors' responsibility for announcing anomalies in a fetus or infant to the respective parents. Studies that seek to identify the feelings that these professionals experience are needed, providing a basis for future intervention projects and assistance in this difficult process (Ptacek et al., 2001).

With regard to the above, the goal of this study is to identify and describe the feelings experienced by health professionals, and more specifically, gynecologists, obstetricians, and ultrasonographists, who have experienced the task of notifying a couple that their child has been or will be born with some defect or handicap. Another goal was to determine the behavior of professionals at the time in which they notify the couple of the problem with the child (how they relate to the couple, what they say, in what way, and at what moment), as well as to identify who makes the announcement.

\section{Method}

\section{Participants}

To perform this research, 10 obstetrician-gynecologist physicians and/or ultrasonographists, licensed for over 2 years and who had already had the experience of notifying parents that their child was born with some abnormality or that their unborn child possessed some defect, were interviewed. These professionals work in the public and private health networks of the city of Ribeirão Preto (Brazil), and consist of 8 obstretician-gynochologist physicians and 2 ultrasonographists. There were 7 men and 3 women. The age of the participants varied between 31 and 56 years, with an interval of 8 to 30 years of licensed practice; 7 of them had graduated from public institutions and the remaining 3 from private schools.

\section{Procedure and Data Analysis}

The interviews were conducted with a semi-structured script containing the topics of personal data, professional training, choice, and professional performance, and preparation for giving such news. The interviews were carried out in the professionals' offices and they lasted about 30 minutes. They were recorded in audio and subsequently transcribed.

The data were qualitatively analyzed according to the thematic analysis of content described by Minayo (1993), who stated that this analysis departs from a superficial reading to reach a deeper level that exceeds the obvious significance. Thematic analysis requires the researcher to carry out an initial exhaustive reading of the verbal material, transcribing the entirety thereof, in order to preclude the loss of any information. Then, depending on the proposed goals and the variables of the study, the material is classified into categories related to the topic of the investigation. And, finally, these data are interpreted according to the theories and studies that support the study.

Qualitative analysis seeks to comprehend the significance of the spoken words or other behaviors observed in the subjects, interconnected to the context in which they occur and unlimited by the researcher's conceptual subjectivity and, when editing, applying a systemization use based on quality, without meaning to exhaust the representative nature of the material (Biasoli-Alves, 1998). A qualitative sample should give preference to the subjects who possess the attributes that the investigator intends to investigate, and a number of interviews must be conducted in order to allow some reiteration of information (Minayo, 1993).

In this study, the following thematic categories were established: (a) the professionals' behavior at the time of disclosure, (b) the time of the disclosure; (c) who informs the parents about an abnormality in their child, (d) the feelings of the professional upon disclosure, and (e) evaluation of graduate courses. They are illustrated with phrases taken from the reports of the actual participants, and explained and discussed.

\section{Results and Discussion}

We were seeking the opinion of the physicians about their behavior when informing parents about an abnormality in their fetus or baby. The aim of the investigation was to identify the time at which this must be done, who should inform the parents, and what feelings are experienced at the time of making this information known.

\section{Professionals' Behavior at the Time of Disclosure}

It was observed that there is no standard behavior on the part of the interviewed professionals at the time of notifying parents of an abnormality in their child. Great difficulty in defining how to proceed at this time was revealed, which is illustrated by the following reports.

I try to inform the mother or father to the extent that they wish to be informed. I think this is a very important issue: to give neither more nor less information at a certain time. (7) ${ }^{1}$

There is no special recipe. I think that each case is unique, in my opinion, and it's working well this way. (5)

\footnotetext{
1 To guarantee the anonymity of the participants, we used the numbers 1 through 10 to identify their responses.
} 
At the same time that there is no standard behavior, it was also observed that each professional does assign importance to a specific procedure at the time of disclosure. Some were more concerned with the reception and effective explanation, others with the clarity of the information.

Regarding behavior, there is no completely satisfactory way to communicate the diagnosis to the parents, as the fact itself carries a great deal of sadness and despair. However, the manner in which the news that their child has some abnormality is transmitted to the parents is believed to be of utmost importance, because the magnitude of the emotional injury to the family dynamic depends on this, and, consequently, the mobilization and investment in the development of the child's potential (Amaral, Cortez, Hoffman, \& Lyra-Neto, 1985).

Tedesco (1997) pointed out the importance of the attitudes with which the professional reacts to the reception of the news, indicating that it is essential to shelter the expectant mother: to be the channel that drains anxieties and sadness; to indicate, explain, orient, to be kind and benevolent. According to this author, a gesture of comfort and care is worth more than any technical explanation.

I think that the first thing is to shelter these parents, and provide

a clarification of what is happening. I believe the clarification to be of great importance; to shelter and to clarify. (2)

It is considered that the physician's first obligation to establish a good relationship with the patients and the respective family members should be to soften the blow, as such behavior facilitates communication when these professionals need to give further information. Just as a tactful and sheltering attitude is important and is observed in the literature, providing clear information and some explanation of the pathology are also important. The news must be given to the couple with clarity and that information about the problem, including any necessary referrals, must be offered (Regen et al., 1993).

The professionals participating in this study agreed, relating that:

It is necessary that the news be clearly stated, without

leaving anything in the air, because I think that, regardless of

how hard it is, you have to speak and you have to back up what you claim. (4)

From the beginning of the conversation about the baby's abnormality, doctor and parents must understand each other mutually, so that any doubts or questions, and not only those of comprehension, are answered. Such information must be communicated correctly and carefully because, if misunderstood, it can result in further negative emotional consequences for the family (Vaidya et al., 1999).

Hania (2003) emphasized that in order to attain their (medical) goal, when results are observed, the information should be clear and comprehensible, and any obscure medical terms should be explained. It must, therefore, necessarily be adapted to the parents' level of comprehension.

From the results obtained, the importance of support for the parents can also be seen. Some professionals emphasize the importance of the presence of other family members at the time the diagnosis is communicated, thus establishing a family support network.

I don't like to give the news alone; I prefer to break the news with other people near the patient... (9)

Buscaglia (1993) stressed the importance of the presence of other people, especially the spouse, at the time of the disclosure. If possible, this author recommends that both parents be present at the initial meeting to avoid future misinterpretation due to the inability or reluctance of one of the spouses to communicate the information. The emphasis on communicating the facts to the couple, not just to one of the spouses, presupposes that they will help each other mutually. If the couple is sound, when one of the members falters, the other tries to be strong and support him or her. Furthermore, the topic can be spoken of openly, which relieves the family atmosphere (Regen et al., 1993).

In addition to family support, the support of their own physician is important, informing them in a correct, yet friendly and respectful way.

I don't beat about the bush. When it's time to tell the parents,

I try to be as friendly and understanding as possible; I take them to another room; I don't keep showing them tests. (10)

The reports from the physicians participating in this study show that they consider that, in addition to not being patronizing, their behavior should be tactful, cushioning; the diagnosis must be given clearly and without using technical terms, as the professionals should be concerned about offering support to the parents, clarifying their doubts, and referring them to specialized care.

The study of Ptacek et al. (2001) shows that the doctors are concerned with establishing behavior that can facilitate the parents' comprehension and minimize their suffering. To inform with simple and coherent language, personally, and in a reserved, peaceful room, are some of the behaviors they recommend. Physicians must be prepared to inform the parents, who are anxious about their child and stunned by what they've been told, of the diagnosis in an objective, yet sympathetic manner. Going even further, some authors remind doctors that it is important for the professional to be capable of understanding the emotional limitations and conditions of the people before them and to be aware of the anxiety experienced by them at that time, serving as an element both of information and support (Ramos et al., 1985; Taanila et al., 1998).

\section{Time of the Disclosure}

None of the physicians interviewed were able to define the best time to give this kind of news. Each one behaves according to their own experience.

The time is when they are ready to hear you. (6)

It is the time at which I am sought out. (7)

So, you have to wait for the crisis to pass to arrive at the right time. (5) 
From the reports, it was observed that the physicians in this study believed that the news must be given only at the time when the family and the doctor are ready to discuss the situation: the parents being able to ask their questions and the physician being ready to and capable of answering them. Thus, the right time would be defined both by the family and the doctor.

Ramos et al. (1985) suggested that the best time to give the news is between the $5^{\text {th }}$ and $30^{\text {th }}$ day after the child's birth, and never later, which means the diagnosis must be given within the $1^{\text {st }}$ month of life. If given at the maternity ward, it must not be at the time of discharge; there should be time for discussion and for the necessary support for the family. Amaral et al. (1985) were even more specific, stating that the notification be given after the first 24 hours, particularly if the parents already suspect a problem. Thus, the doctor avoids keeping the parents in a state of anxiety about the unknown. Regen et al. (1993) also suggested that it is important to allow the mother to recover from the delivery of the newborn infant and to give the news to the couple in the presence of the baby, preferably long before mother and baby are discharged from the hospital. This way, the parents can ask all questions they need to and clear up their doubts.

As far as prenatal diagnostics, in this work, we observed that, in these situations, it is usually the ultrasonographists who inform the expectant family about the fetus' abnormality, and they do it at the time the examination is performed. An important variable with regard to this is the viewing of the fetus. The use of ultrasound, by itself, in the prenatal period affects the parents' perception of the fetus, either favoring or hindering the acceptance of the child. Consequently, these authors underscore that the ultrasonographists' attitude is essential; they should be attentive to excessive worries, clarifying doubts and questions, and giving support in stressful situations. This is because, when prenatal monitoring is performed, the level of maternal anxiety creates doubts about the integrity of the fetus and the pregnancy after the results of an examination or ultrasound imaging of some abnormality. Thus, it is important that the professionals in this field clarify any questions that may arise when the parents are able to see the fetus, thus reducing the level of stress for the family (Hertling-Schaal, Perrotin, Poncheville, Lansac, \& Body, 2001; Quayle, Brizot, \& Zugaib, 1999).

\section{Who Informs the Parents about an Abnormality in their Child}

A large difference was observed in the behavior or procedure of the public health network and private clinics, where the patients' own doctor monitors the pregnancy, and notifies them of the diagnosis.

It's always me. I think this responsibility falls to the professional monitoring the client. (1)
Even when it's a more specific matter that the pediatrician could clarify better, about which I don't have as much knowledge, I try to be with the pediatrician. (4)

In the public health network, due to the characteristics of this service, where there is no physician who monitors the expectant mother for the entire pregnancy, the notification is provided by whichever doctor is on duty at the time of the consultation.

... So, it could be me, it could be a resident or another colleague, or a geneticist who performs this function. (7)

This behavior is considered inappropriate. To delegate the responsibility of informing the parents to the least experienced person, or to a professional who has no connection with them, can impede their comprehension of the information and their acceptance of the diagnosis. Less experienced professionals can be emotionally ill-prepared, and may not have the necessary knowledge to clarify the questions that the parents' might need to ask. The lack of professional experience is important because, generally, the least experienced individuals are given the responsibility for this function, and, due to this lack of experience, the hoped-for good relationship can disintegrate (Tedesco, 1997).

Neither the amount of education nor the level of training is directly related to the emotional reactions. Particularly, recently graduated doctors report a need for emotional support when they have to communicate bad news to parents. This is essential because, in most cases, these recently graduated doctors - generally on-duty obstetricians - are the ones who perform the deliveries in large hospitals. These doctors have no previous relationship with the mother, which is fundamental at the time in which a child with an abnormality is born (Ramos et al., 1985; Redinbaugh et al., 2003).

\section{Feelings of the Professional upon Disclosure}

All of the professionals who participated in this study reported that they felt bad, frustrated, and even guilty when they had to notify parents of an abnormality in their child. They considered it as difficult and painful for them as it was for the parents. Some doctors said that they become involved in the situation, experiencing the same emotions that their patient feels. Others, however, said that, despite feeling very badly, they try not to become emotionally involved.

I feel bad, I feel bad, it is always very painful, it's always very sad. (4)

I get involved; to this day, I have not gotten used to it. (5)

And, when we have to... that mask that we put on, we can't remain distant from the problem, remain distant from the patient, like I said, but, neither can we go to the other extreme ... Now, personally, surely you are uncomfortable... (8)

Very bad.... So, I try to be professional, each case is unique, and I try to act accordingly...(7)

Doctors frequently speak about their emotional involvement, even those who try to distance themselves, and act "professionally." When confirming an anomaly in 
the fetus, the doctor places his or her own competence in doubt, as such, and anger toward the unborn child may emerge. This is because the desire to struggle against death, suffering, and pain is the most important issue for the doctor. Consequently, professionals may feel guilty for feeling anger, rejection, and aggression, and therefore develop a defense mechanism that is strong enough to survive the daily routine with their own worries, suffering, and the remembrance of their own mortality and end. Thus, when dealing with a situation of loss so similar to death, the professionals in this study clearly revealed the need to use defense mechanisms to overcome their own "faults." Such mechanisms may be explained because the parents of physically or mentally deficient children are in a constant state of conflict about the normal child they don't have, that they hoped and wished for, but that did not materialize. It is extremely difficult for the physicians to deal with the struggle and suffering of this family, for various reasons. This struggle puts them in contact with their own suffering and mortality, which, logically, they would prefer to forget, as it is a threat to their omnipotence ((Bellodi, 2001; Gauderer, 1981; Quayle, 1997)).

In this situation, it becomes very clear that neither education, professional experience, the university where one studied or carried out one's residence, nor one's medical specialty, gender, or age make any difference. The feelings experienced are awful.

It can even be observed that, for some professionals, seeking competence is also tempered by the capacity to reevaluate themselves, as much technically as emotionally.

I think I've been worse; now we are trying to work better.(4)

The perception of one's own values and feelings is of fundamental importance to the establishment of a proper doctor-patient relationship. There is a need to develop objective self-awareness on the part of the professional. Medical education ignores the importance of emotional support, focusing entirely on biomedical matters (Redinbaugh et al., 2003; Tedesco, 1997).

Considering these facts, the presence on the team of a mental health professional who could deal with the emotions and psychological welfare of these doctors, thus providing the support they need, is believed to be of great importance.

\section{Evaluation of Graduate Courses}

Evaluating the training that they received with regard to facing the emergent questions of a prenatal diagnosis, the great majority of the professionals in this study said they lacked training to prepare them to deal with topics related to malformation or deficiency.

Look, I see it this way: I can't complain about the education I received... and we had the opportunity to receive excellent surgical training, and training for sensitivity and feelings, you know, we can get in the hospital. (1)
The graduate course in itself, I think that it really values success - the final result and success-so much so that we really aren't well prepared for death, right? (2)

...We weren't prepared to deal with death, with failure. (3)

Zero, zero, zero, zero, working with crises is not taught... (9)

I see it as completely insufficient; each person ends up doing what their intuition tells them, because there is no specific training for this. There is nothing else that you can do to help the patient, beyond the technical things. (4)

They fail to teach doctors how to treat the patient with respect and dignity; I mean, in the human sense, you know; the patience that the doctor must have with the patient, to value their complaints; when the patient comes along with a complaint, they are not playing. I really feel the lack of this now. (5)

Unfortunately, it keeps getting worse. I believe that this needs to be improved; it must. I believe that our course is one that places the student the most closely in contact with the patient, there are so many people that are educated there...I think the more distrusted the approach, I think the training would make us feel more secure... (6)

But really, it's very deficient, very deficient. You learn on your feet, really, these experiences...(8)

As it is now, which isn't good, I think it's no good lacking thus, the way it is, we are having to give a nine-year course... (10)

It can be observed through the reports that only one of the professionals interviewed confirmed that his university training prepared him to work with the problem of deficiency; the others stated that they had not had any preparation or that what they did receive was inadequate, mainly in the area of human relations. They focused on the fact that their education prepared them only to deal with success, life, cure, and not with failure and death, emphasizing once more the fact that medical courses give preference to biological and biomedical matters, at the expense of human issues.

Tedesco (1997) approached this issue rather forcefully, warning about professional unpreparedness and the lack of technical conditions in graduate courses. Moreover, the matter of a deficiency is addressed in a very limited way in medical courses (Buscaglia, 1993).

\section{Conclusions}

The purpose of this study was to identify and describe how professionals feel when they have to inform parents about a malformation or abnormality in their baby, and, even, to explore their behavior at the time they give such news. The results presented here show that the physicians are very sensitive to the condition of the family; however, the majority does not feel adequately prepared to deal with the situation. 
Thus, primarily, we see the need for including psychological studies in graduate courses, in which issues of family dynamics and deficiency are addressed. This is because physicians must remind themselves that some cases require special knowledge, skill, wisdom and humanity and more than a short amount of time dedicated to the parents (Andreson \& Garner, 1973, as cited in Buscaglia, 1993). From the same perspective, Hertling-Sehaal et al. (2001) indicate the need for training and doctors' involvement in the aspects of psychological and emotional care of expecting mothers, thus enabling a better doctor-patient relationship, and, consequently, greater security for the expecting mother.

According to the physicians in this study, the feelings that arise during the process of disclosing a malformation or deficiency are always unpleasant, regardless of their professional experience, time of education, the college where they studied or carried out their residence, their medical specialty, gender, or age. In addition to a greater period of specific preparation for the doctor, they suggest that effective participation of a mental health professional in the multiprofessional team is desirable, for two reasons: primarily, to deal with the possible insecurity that doctors feel, and so that they succeed in attending to their own anxiety, without placing their performance and effectiveness at risk. And, consequently, so that the doctors truly shield the expectant mother, becoming the channel that draws off her anxieties and sadness; they should explain and orient, be kind and benevolent (Quayle et al., 1999; Tedesco, 1997).

Lastly, this study addressed some issues that reveal the emotional difficulty of the professional doctors interviewed when dealing with matters related to deficiencies, and, more specifically, when informing the parents of the child of the deficiency. In a study with qualitative methodology, such as the present one, quantitative analyses and generalizations are not relevant. Therefore, the importance of new studies in the area is noted, as the matter is complex and not well studied.

\section{References}

Amaral, M.J.C., Cortez, M.L.S., Hoffmann, V.M.B., \& Lyra-Netto, T.C. (1985). Programa de apoio aos pais. Projeto "Momento da Notícia." São Paulo, Brazil: APAE.

Amiel, G.E., Ungar, L., Alperin, M., Baharier, Z., Cohen, R., \& Reis, S. (2006, January) Ability of primary care physician's to break bad news: A performance based assessment of an educational intervention. Patient Education and Counseling, $60,10-15$.

Assumpção Junior, F.B. (1991). A família e o deficiente mental. São Paulo, Brazil: Ed. Paulinas.

Bellodi, P. L. (2001). O clínico e o cirurgião. Estereótipos, personalidade e escolha de especialidade médica. São Paulo, Brazil: Casa do Psicólogo.

Buckman, R. (1992). How to break bad news: A guide for healthcare professionals. Baltimore: John Hopkins Press.
Buckman, R. (2002). Communications and emotions. Skills and effort are key. Editorials. British Medical Journal, 325, 672.

Buscaglia, L. (1993). Os deficientes e seus Pais. Um desafio ao aconselhamento. Rio de Janeiro: Editora Record.

Gauderer, E.C. (1981). Reação do profissional frente à doença crônica ou fatal. Jornal Brasileiro de Medicina, 40, 47-56.

Han, P.K.J., Keranen, L.B., Lescisin, D.A., \& Arnold, R.M (2005). The Palliative Care Clinical Evaluation Exercise (CEX): An experience-based intervention for teaching end-of-life communication skills. Academic Medicine,80, 669-676.

Hania, C. (2003). De l'information à la parole. La position du psycologue. Gynécologie Obstetrique \& Fertilité, 31, 452-455.

Hertling-Schaal, E., Perrotin, F., de Poncheville, L., Lansac, J., \& Body, G. (2001). Maternal anxiety related to prenatal screening and invasive testing: Detection and management. Gynecology Obstetrique \& Fertilite, 29, 440-446.

Hulsman, R.L., Mollema, E.D., Oort, F.J., Hoos, A.M., \& De Haes, J.C.J.M. (2006). Using standardized video cases for assessment of medical communication skills: Reliability of an objective structured video examination by computer. Patient Education and Counseling, 60, 24-31.

Mast, M.S., Kindlimann, A., \& Langewitz, W. (2005). Recipients' perspective on breaking bad news: How you put it really makes a difference. Patient Education and Counseling, 58, 244-251.

Minayo, MC. da S. (1993). O desafio do conhecimento: pesquisa qualitativa em saúde. São Paulo- Rio de Janeiro: Hucitec Abrasco.

Noronha, D., \& Montgomery, M. (1993). O obstetra, o casal e o recém-nascido malformado. In D.T. Noronha, G.P. Lopes, \& M. Montgomery (Eds.), Tocoginecologia psicossomática (pp. 63-70). São Paulo, Brazil: Almed.

Ptaceck, J.T., Ptaceck, J.J., \& Ellison, N.M. (2001). "I'm sorry to tell you..." Physicians' reports of breaking bad news. Journal of Behavioral Medicine, 24, 205-217.

Quayle, J. (1997). Óbito fetal e anomalias fetais: repercussões emocionais maternais. In J.J. de A. Tedesco, M. Zugaib, \& J. Quayle (Orgs.). Obstetrícia psicossomática (pp. 216-227). São Paulo, Brazil: Ed. Atheneu.

Quayle, J., Brizot, M.L., \& Zugaib, M. (1999, November). Psychological aspects associated with ultrasound scan and nuchal translucency. 9th World Congress of Ultrtasound In Obstetrics and Gynecology. Buenos Aires (Argentina).

Ramos, T.C.L., Hoffmann, V.M.B., \& Regen, M. (1985). As dificuldades em transmitir a notícia: pesquisa junto a pais de pacientes portadores de Síndrome de Down. Revista Brasileira de Deficiência Mental, 18, 47-69.

Redinbaugh, E.M., Sullivan, A.M., Block, S.D., Gadmer, N.M., Lakoma, M., Mitchell, A.M., Seltzer, D., Wolford, J., \& Arnold, R.M. (2003). Doctors' emotional reactions to recent death of a patient: Cross-sectonal study of hospital doctors. British Medical Journal, 327, 185-190.

Regen, M., Ardore, M., \& Hoffmann, V.M.B (1993). Mães e Filhos Especiais: Relato de experiências com grupos de mães de crianças com deficiência. Brasília: CORDE. 
Taanila, A., Järvelin, M-R., \& Kokkonen, J. (1998). Parental guidance and counselling by doctors and nursing staff: Parents' views of initial information and advice for families with disabled children. Journal of Clinical Nursing, 7, 505511.

Tedesco, J. J. de A. (1997). A humanização da relação obstetramãe-filho. In J. J. de A. Tedesco, M. Zugaib, \& J. Quayle (Orgs.), Obstetrícia psicossomática (pp. 271-279). São Paulo, Brazil: Ed. Atheneu.

Ungar, L., Alperin, M., Amiel, G.E., Beharier, Z., \& Reis, S. (2002). Breaking bad news: Structured training for family medicine residents. Patient Educational and Counseling, 48, 63-68.

Vaidya, V.U., Greenberg, L.W., Patel, K.M., Strauss, L.H., \& Pollack, M. M. (1999). Teaching physicians how to break bad news. A 1-day workshop using standardized parents. Archives of Pediatrics \& Adolescent Medicine, 153, 419-422.

Vicente, A. T. (1994). Pensando o espaço terapêutico a partir dos conceitos de paciente e cliente. In R.M.S. de Macedo (Org.), Terapia familiar no Brasil: Estado da Arte. Anais (vol.II), 1, Congresso Brasileiro de Terapia Familiar (pp. 55-61). São Paulo, Brazil: SP.

Wilheim, J. (1997). Psiquismo pré e perinatal. In J. J. de A. Tedesco, M. Zugaib, \& J. Quayle (Orgs.), Obstetrícia psicossomática (pp. 260-267). São Paulo, Brazil: Ed. Atheneu.

Received March, 6, 2006 Revision received October, 5, 2006 Accepted June, 4, 2007 